\title{
Biotite dehydration, partial melting, and fluid composition: Experiments in the system $\mathrm{KAlO}_{2}-\mathrm{FeO}-\mathrm{MgO}-\mathrm{SiO}_{2}-\mathrm{H}_{2} \mathrm{O}-\mathrm{CO}_{2}$
}

\author{
A.A. Graphchikov, ${ }^{1}$ A.N. Konilov, ${ }^{1}$ and J.D. Clemens ${ }^{2, *}$
}

Institute of Experimental Mineralogy, Russian Academy of Science, 142432 Chernogolovka, Moscow District, Russia ${ }^{2}$ School of Geological Sciences, CEESR, Kingston University, Penrhyn Road, Kingston-upon-Thames, Surrey, KT1 2EE, U.K.

\begin{abstract}
Biotite solid-solutions are a significant $\mathrm{H}_{2} \mathrm{O}$ reservoir in the lithosphere, and the assemblage $\mathrm{Bt}+\mathrm{Opx}+\mathrm{Kfs}+\mathrm{Qtz}$ is commonly used to estimate $a_{\mathrm{H}_{2} \mathrm{O}}$ in high-grade metamorphic and magmatic rocks. Here we report experimental constraints on subsolidus mineral equilibria involving biotite and orthopyroxene in the system $\mathrm{KAlO}_{2}-\mathrm{MgO}-\mathrm{FeO}-\mathrm{SiO}_{2}-\mathrm{H}_{2} \mathrm{O}-\mathrm{CO}_{2}$. Our experiments address the question of stability of biotite of a given $X_{\mathrm{Fe}}$ in the assemblage $\mathrm{Bt}+\mathrm{Qtz} \pm \mathrm{Sa}$, or the stability of the assemblage Opx $+\mathrm{Sa} \pm \mathrm{Qtz}$. Clemens (1993) and Clemens et al. (1997) concluded that $\mathrm{CO}_{2}$ has no effect other than to lower $a_{\mathrm{H}_{2} \mathrm{O}}$ and thereby raise the solidus $T$. Our data at $X_{\mathrm{H}_{2} \mathrm{O}}^{\mathrm{F}}<1$ extend these conclusions to encompass Fe-bearing systems more similar to natural rocks. From a comparison of experimental data and calculated isopleths of biotite composition in the divariant assemblage $\mathrm{Bt}+\mathrm{Opx}+\mathrm{Kfs}+\mathrm{Qtz}+\mathrm{fluid}$, it appears that phlogopite-annite solid-solutions must be significantly non-ideal (at $T<$ $800{ }^{\circ} \mathrm{C}$ ) or that enstatite-ferrosilite solid-solutions must have negative values for their Margules-type parameters. Ignoring these factors would result in any calculated $a_{\mathrm{H}_{2} \mathrm{O}}$ values being too low. Although various models allow us to estimate $X_{\mathrm{H}_{2} \mathrm{O}}$ in $\mathrm{H}_{2} \mathrm{O}-\mathrm{CO}_{2}$ fluids, we are still unable to use biotite equilibria to estimate $a_{\mathrm{H}_{2} \mathrm{O}}$ accurately during high-grade metamorphism and magma crystallization. We also consider qualitatively the effects $\mathrm{Fe}-\mathrm{Mg}$ biotite solid-solution on partial melting equilibria in fluid-poor (rock-dominated) systems in which hydration-dehydration reactions control the fluid composition.
\end{abstract}

